Research Article

\title{
Methods to describe the botanical composition of vegetation in grassland research
}

\author{
Methoden zur Beschreibung des Pflanzenbestandes \\ in Grünland-Feldversuchen
}

\author{
Giovanni Peratoner ${ }^{1 *}$, Erich M. Pötsch² \\ ${ }^{1}$ Laimburg Research Centre, Vadena/Pfatten, 39040 Ora/Auer, Italy \\ ${ }^{2}$ Agricultural Research and Education Centre Raumberg-Gumpenstein, Raumberg 38, 8952 Irdning-Donnersbachtal, Austria \\ * Corresponding author: giovanni.peratoner@laimburg.it
}

Received: 11 October 2018, received in revised form: 21 December 2018, accepted: 22 December 2018

\begin{abstract}
Summary
In terms of botanical composition, grassland vegetation in experimental plots and field studies can be described by means of different parameters (plant density, cover, frequency or yield proportion). Each parameter describes different features, which under certain circumstances may be correlated one to each other to some extent, but are not fully equivalent. The choice of the parameter to be assessed depends therefore, in first instance, on the specific aim of the investigation. For the assessment of the chosen parameter, many methods are available that differ from each other in terms of subjectivity, precision, effort and requirement for technical equipment. The choice of method depends mainly on the required precision, the affordable effort and on the available resources.
\end{abstract}

Keywords: grassland, botanical composition, parameters, assessment methods

\section{Zusammenfassung}

Die Charakterisierung des Pflanzenbestandes in Versuchsparzellen und Feldstudien hinsichtlich der botanischen Zusammensetzung kann durch die Erhebung verschiedener Parameter wie Pflanzendichte, Deckungsgrad, Frequenz oder Ertragsanteile erfolgen. Jeder Parameter beschreibt unterschiedliche Aspekte, die unter bestimmten Bedingungen zu einem gewissen Maß korreliert, aber nicht äquivalent sind. Die Auswahl des zu erhebenden Parameters leitet sich daher in erster Linie aus dem spezifischen Ziel der Untersuchung ab. Für die Erhebung selbst stehen zahlreiche Methoden zur Verfügung, die sich hinsichtlich Objektivität, Genauigkeit, Aufwand und Notwendigkeit einer entsprechenden Ausrüstung unterscheiden. Die Auswahl der Erhebungsmethode hängt im Gegensatz zur Auswahl des Parameters von der zu erzielenden Genauigkeit sowie vom vertretbaren Aufwand für deren Durchführung und von den verfügbaren Ressourcen ab.

Schlagworte: Grünland, botanische Zusammensetzung, Parameter, Erhebungsmethoden 


\section{Introduction}

In grassland science, the characterization of vegetation in terms of its botanical composition is one of the most important aspects. The botanical composition of grassland reflects both the site conditions and management factors. Their changes affect the botanical composition, which in turns has an impact on yield and forage quality. Changes in the botanical composition over time provide relevant hints about the impact of environment and management on vegetation. As most of grassland vegetation is perennial or even permanent, vegetation dynamics enable to identify medium and long-term effects. For this reason, the description of the botanical composition of meadows and pastures is essential in grassland science and is therefore an indispensable part of monitoring and analysis both in field trials and field surveys. Grassland vegetation can be surveyed at different scaling levels: from a global point of view with the help of remote sensing up to small areas using different methods. It is possible to switch between these scales, whereas the aggregation of detailed data to a global scale is much easier rather than the other way round (Burrough, 1986; Whalley and Hardy, 2000).

This paper is dealing with different options and methods to analyze the botanical composition of grassland vegetation, and provides, without claiming completeness, an overview of the most relevant parameters and methods as a function of the given aims of the study. The focus is mainly set on manipulative field experiments and field studies with agronomic and/or ecological background and arranged in differently scaled plots rather than on vegetation monitoring or vegetation mapping; although many concepts discussed here are relevant to both application fields.

\section{Parameters to describe the botanical composition of grassland swards}

In the first step, appropriate parameters for the description of the botanical composition must be selected. In general, the pure qualitative description of botanical composition by means of a species list is insufficient to gain agronomically relevant information in grassland science, whilst much better insight is provided by quantitative parameters. As an aid to the definition of the main parameters, we also provide a graphic explanation (Figures 1 to 7 ), based on an exemplificatory plant community composed by three species differing in size and structure.
Density is representing the number of individuals per area unit (Figure 1). This parameter is of great importance to evaluate the quantitative effects of measures to regulate or control weeds on the number of plants or plant parts, usually applied to selected target species. In practice, the identification of single individuals is a big challenge in the case of high density of coalescing species that grow stolons, those generating more stems from the same root system, or those having in general a clonal growth. But density can be recorded even in such cases as long as a standardized counting unit is defined. Under specific circumstances, the density of stems can be more relevant than the number of individuals to quantify the occurrence of a species and describe its changes over time (Müller-Dombois and Ellenberg, 1974). In pastures, the density of tillers per unit area is often used for grass species, whilst the density of activated growing points (terminal buds of the stolons) can be used for white clover (Grant, 1993). If the size of plants or plant parts is relatively homogeneous, their density provides an indirect figure of their biomass as well. Moreover, if the counted units are relevant to reproduction or multiplication processes, density data also provide information on population dynamics.

Cover is the proportion of the surveyed area that is covered by the vertical projection of the above-ground plant parts (Figure 2). Considering only the topmost plant parts (Figure 3a), the total cover cannot exceed $100 \%$ and the assessed parameter is called top cover (Greig-Smith, 1983). The difference between $100 \%$ and the top cover corresponds to the proportion of vegetation gaps, representing the proportion of bare soil. If the assessment of the proportion of bare soil aims at quantifying damages due to, for example, root vole, mole, grubs, trampling and track damage, it should be surveyed right after cutting or grazing. If the aim of the investigation is instead quantifying the protection of soil against erosion given by the vegetation, the assessment may be meaningful also with undisturbed vegetation. In some cases, cover is also considering the overlapping plant parts (Figure $3 \mathrm{~b}$ ) and can then be more than 100\% (Schechtner, 1958; Whalley and Hardy, 2000; Kirmer, 2004). Furthermore, it is also distinguished between basal cover and canopy cover, where the former only considers the plant basis, whereas the second one accounts for all the above-ground plant parts (Whalley and Hardy, 2000). Cover is most frequently used in vegetation ecology and plant physiological studies. However, top cover is of high relevance for the evaluation of protection against soil erosion, as there is a strong relationship between vegetation cover and soil erosion (Copeland, 1965; Linse et al., 2001). 




Figure 1. Plant density

Abbildung 1. Pflanzendichte

Frequency is the proportion of cases, in which a certain species can be detected at a defined number of observation points or sub-areas (Figure 4). Frequency rather gives evidence of uniformity of distribution than of abundance in case of individuals growing clumped (Müller-Dumbois and Ellenberg, 1974; Greig-Smith, 1983). This parameter is most suitable to investigate vegetation dynamics when observation plots are repeatedly surveyed in time series (Bonham, 2013). Daget and Poissonet (1971) derive specific contribution (French: contributions spécifiques) from frequency values by calculating the proportion of a certain species frequency over the sum of the frequencies of all species.

Yield proportion (Figure 5) represents the relative proportion (weight-\%) of harvestable above-ground dry matter biomass of a certain species or a species group related to the total dry matter yield (Klapp, 1930; cited in Voigtländer and Voss, 1979). This parameter is particularly suitable for agronomic studies with a special focus on forage production and forage quality. Yield proportion on its own also gives an insight into the competitive relationship between species, and does not necessarily provide information on their absolute abundance, unless this information is combined with yield data. In this case, the product of the yield proportion of a certain species by the yield of the entire community allows to estimate the yield of this species.

Depending on the analyzed parameter, meaning and value of the generated information differ. For example, a species with very small individuals homogenously distrib-



Figure 2. Plant cover

Abbildung 2. Deckungsgrad 


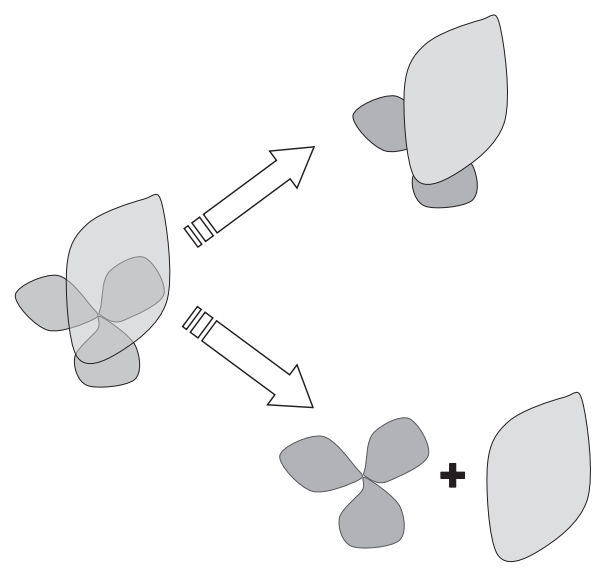

a) Top cover: in case of overlapping

plant parts, only the upper one is

considered

$\Rightarrow$ total cover cannot exceed $100 \%$

Bare ground $($ gaps) $=100-$ top cover

b) Cover: all above-ground plant parts, including the

overlapping ones, are considered

$\Rightarrow$ total cover can be more than $100 \%$

Figure 3. Difference between a) top cover and b) cover in case of overlapping plant parts

Abbildung 3. Unterschied zwischen a) Deckungsgrad unter Berücksichtigung nur der oberen Pflanzenteile im Fall von Überlappungen (top cover) und b) Deckungsgrad unter Berücksichtigung aller Schichten

uted across the area being assessed in combination with other tall, evenly distributed species would indeed exhibit high frequency and plant density but low cover and low yield proportion (Figure 6a). The same species, if growing clumped, would still exhibit high plant density, but low frequency (Figure 6b).

Both yield proportion as well as cover provides information on the quantitative occurrence of species. Although being two different parameters to describe vegetation, it is often assumed that they give similar estimation values. This applies particularly to short vegetation, but not in case of taller vegetation. For instance, there are relevant differences when spot-wise distributed tall plants are growing in a dense, short vegetation (Figure 7 ). Larger differences between cover and yield proportion are in general to be expected by using top cover instead of cover which also considers overlapping plant parts and expresses it as a percent of the sum of the cover of all species.

An example of this is provided by Weinzierl (1902), reporting results of the evaluation of a plant community by estimating both yield proportion and cover (Table 1).
Depending on the assessed parameter, strong differences in the proportion occur for some species. For this reason, Weinzierl (1902) points out that assessments focusing on yield proportion are unsuitable to classify plant communities from a phytosociological point of view.

\section{General requirements of survey methods}

\subsection{Selection of an appropriate assessment scale}

In plant ecology, scales based on intervals into which the assessed values fall are often used, resulting in so-called interval-censored data (Onofri et al., 2019). The seven-grade scale of Braun-Blanquet (1964) is used very frequently, which has a variation range of $20 \%$ (class 2 ) resp. $25 \%$ (class 3,4 and 5). This scale is a so-called abundance/dominancescale, and is used to estimate the species occurrence taking also into consideration the plant density for low cover values (Voigtländer and Voss, 1979). Some ordinal scales offer unequal intervals, with tighter intervals for low cover/yield

Table 1. Classification of a plant community based on different botanical parameters (Weinzierl, 1902)

Tabelle 1. Klassifizierung der Pflanzengesellschaft auf Basis unterschiedlicher botanischer Parameter (Weinzierl, 1902)

\begin{tabular}{|c|c|c|}
\hline Species & Yield proportion (\%) & Cover $(\%)$ \\
\hline Common reed (Phragmites communis) & 25 & 5 \\
\hline Canary grass (Phalaris arundinacea) & 20 & 5 \\
\hline Tall fescue (Festuca arundinacea) & 18 & 10 \\
\hline Bent grass (Agrostis vulgaris) & 17 & 65 \\
\hline 15 other species & 20 & 15 \\
\hline total & 100 & 100 \\
\hline grassland type & $=$ Phragmitetum & $=$ Agrostietum \\
\hline
\end{tabular}




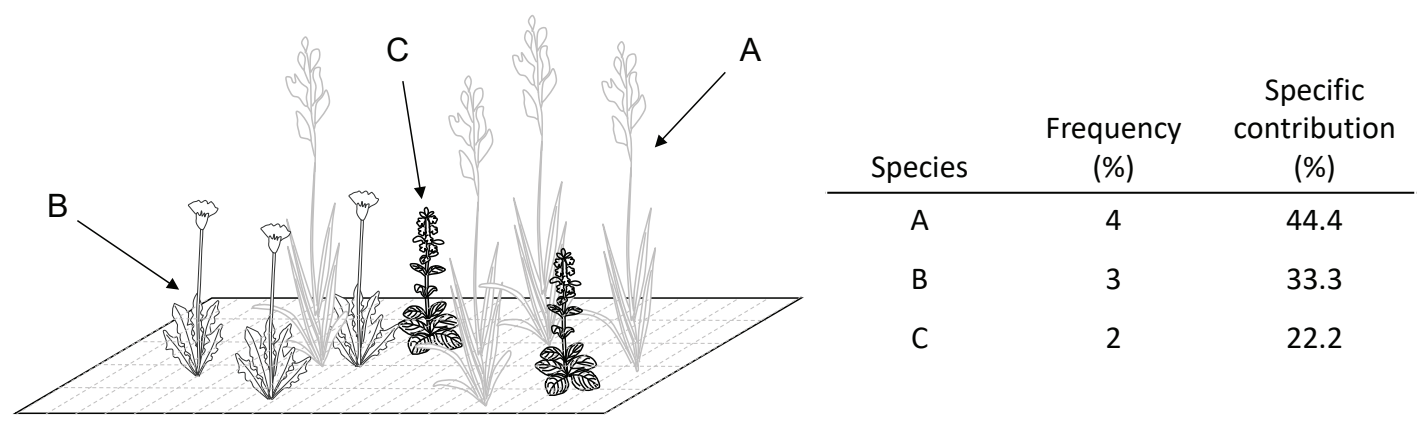

Figure 4. Frequency and specific contribution. The surveyed area has been divided into 100 sub-areas Abbildung 4. Häufigkeit und spezifischer Anteil. Die Erhebungsfläche wurde in 100 Teilflächen unterteilt

proportion and wider intervals for high values (e.g., van der Maarel, 1979; Gauch, 1982; Dietl, 1995). These scales are rather similar to logarithmic scales (Figure 8), which reflect the fact that by means of a visual estimation, it is easier to judge small differences for low values (e.g., between 3 and 5\%), whereas it is almost impossible to properly catch the same difference for high values (e.g., between 45 and $47 \%)$. In case of parameters with their total value being $100 \%$ (i.e., top cover and yield proportion), however, high values can be quite reliably estimated by subtracting first from 100 the less abundant species, which are easier to assess (Traxler, 1997). Logarithmic scales better reflect the human perception than percent scales and avoid claims of excessive accuracy. However, there is some disadvantageous loss of information caused i) by the unknown estimation ability of the single observer (well trained and skilled observers may still catch small differences at high values better than average observers), ii) by the impossibility of an iterative adaptation of the estimate, which in total should account for $100 \%$ when adding all estimated values and iii) by the non-additive properties of these scores, which do not allow for the computation of meaningful sums or means. In such cases, the mid-point of the corresponding interval of the score is often imputed (i.e., a percent value



Figure 5. Yield proportion Abbildung 5. Ertragsanteil 

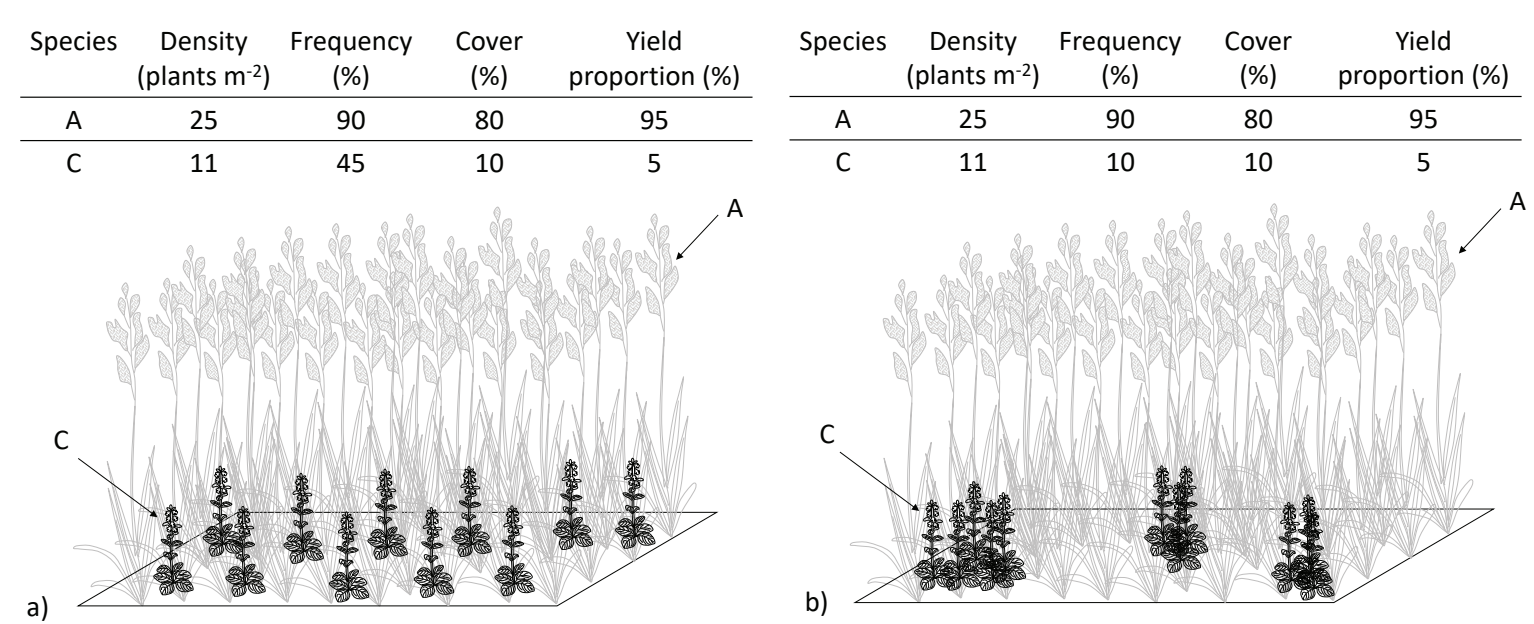

Figure 6. Expression of various parameters depending on the plant size and distribution in the sward Abbildung 6. Ausprägung unterschiedlicher Parameter in Abhängigkeit von Pflanzengröße und -verteilung im Bestand

of 62.5 is assumed instead of a score corresponding to an interval from 50 to $75 \%)$. It is straightforward that the sum of the assumed values of all species cannot reproduce the sum of the real values of the species. They are just a proxy for the real values and, in case of broad intervals, it is unlikely to properly catch differences between experimental units or changes over time being smaller than the interval width. Nevertheless, logarithmic scales are well suited in vegetation ecology for performing ordination procedures and multivariate statistics (Gusmeroli, 2012). There are additional scales like that of Pfadenhauer et al. (1986) using 8 categories, Londo (1976) with 12 categories, the Londoscale modified by Zacharias (1996) using 20 categories or those of Schmidt (1974, cited in Pfadenhauer et al., 1986), Bornkamm and Hennig (1982), Wilmanns (1989) and Dierschke (1994). Censored data can be analyzed by means of the body of techniques known as "survival analysis" (Onofri et al., 2019).

\begin{tabular}{ccccc} 
Species & $\begin{array}{c}\text { Density } \\
\left.\text { (plants } \mathrm{m}^{-2}\right)\end{array}$ & $\begin{array}{c}\text { Frequency } \\
(\%)\end{array}$ & $\begin{array}{c}\text { Cover } \\
(\%)\end{array}$ & $\begin{array}{c}\text { Yield proportion } \\
(\%)\end{array}$ \\
\hline A & 9 & 8 & 7 & 60 \\
\hline B & 144 & 95 & 93 & 40
\end{tabular}

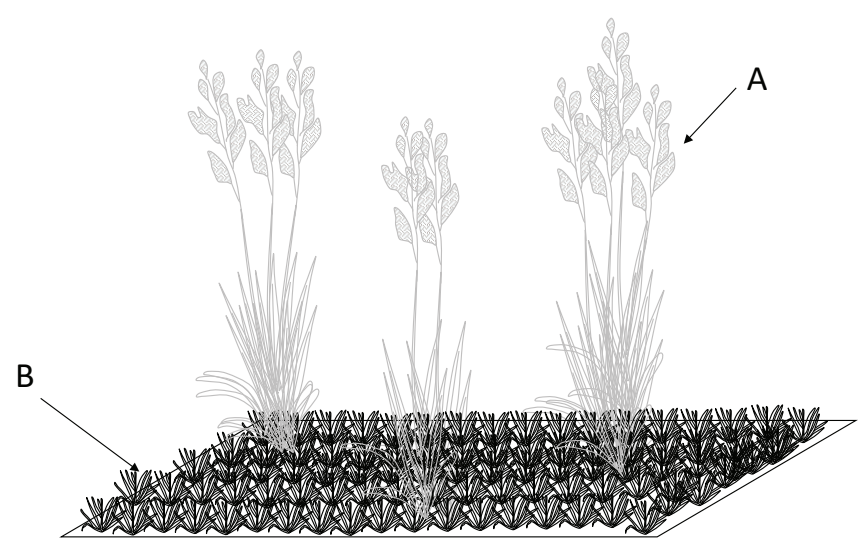

Figure 7. Different expression of cover and yield proportion in a combination of tall, clumped individuals (species A) and a dense, short vegetation (species B)

Abbildung 7. Unterschiedliche Ausprägung von Deckungsgrad und Ertragsanteil bei Mischbeständen mit großwüchsigen, gruppierten Individuen (Art A) und einer dichten niedrigwüchsigen Vegetation (Art B) 


\subsection{Time of assessments}

In most cases, the most suitable time for vegetation assessments on meadows is right before performing the first cut, as most species can be more easily found at this time. At the same time, the vegetation stage of the dominating species should be evaluated as well. As the quantitative parameters of the botanical composition change along the phenological development of species, this information allows for an evaluation of the comparability of data obtained from the same plot in different growing seasons.

In extensive, late-cut grassland, the species determination is made easier by the advanced phenological stage of most plants, allowing to use diagnostic characters of generative organs (e.g., flowers or fruits). In intensively managed grassland, instead, the determination must be mainly based on vegetative organs. If the aim of the survey is an exhaustive description of the botanical diversity, the obtained species list should ideally be controlled and completed during the following regrowths, as some species might easily be missed in the first growth (e.g., fall dandelion) or are developing later. For the regrowths, it is advisable to estimate at least the weight- $\%$ of the species groups of grasses, forbs and legumes to document changes between the different growths.

\subsection{Level of botanical detail}

The aspired level of botanical detail depends on the aim of the survey. Whilst for ecological studies, aiming at charac- terizing the botanical diversity, a complete list of species (and subspecies) is a quite straightforward requirement, other less time-consuming target levels of botanical detail may be reasonable for other aims.

The dry-weight-rank method (Mannetje and Haydock, 1963; Jones and Hargreaves, 1979; Tothill et al., 1992) averages the results of a certain number of assessments in small quadrats. In each quadrat, only the rank of the three most abundant species in terms of yield proportion is recorded and standard values are assigned to the ranks. For instance, this procedure was found to be acceptably accurate for a study aiming at the quantification of community-weighted means of functional traits (Lavorel et al., 2008).

For agronomic studies, the assessment at the species group level of grasses (including also graminoids such as sedges and rushes), legumes and forbs allows classifying the sward into types according, for example, to the Swiss system (Daccord et al., 2007): rich in grasses (> 70\% grasses), balanced (between $50 \%$ and $70 \%$ grasses), rich in forbs (> 50\% forbs, legumes < 50\%) and rich in legumes (legumes $>50 \%$ ). This kind of classification can be quickly learnt and applied by practitioners with reasonable precision even after a short training (Peratoner et al., 2018) and allows in turn obtaining some hints (Table 2) about yield potential (Troxler and Thomet, 1988), forage quality and its stability along the advance of the phenological stage at the first cut of meadows (Nußbaum et al., 1999; Daccord et al., 2007; Peratoner et al., 2016a; 2016b), suitability for silage conservation (Weißbach et al., 1977; Frame and Laidlaw, 2004), drying speed and risk of crumbling losses



Figure 8. Comparison of different nine-part logarithm-like scales

Abbildung 8. Vergleich unterschiedlicher neunteiliger, logarithmusähnlicher Skalen 
at hay making (Höhn, 1988; Frame and Laidlaw, 2004) and risk of contamination with soil (Resch et al., 2014).

\subsection{Selection of a representative survey area}

Especially for investigations with a focus on plant sociology and species diversity, the proper selection of a representative survey area is an important precondition. In managed grassland, such areas should be as homogenous as possible. Bohner and Sobotik (2000) estimated the ideal area size to be about $100 \mathrm{~m}^{2}$ to catch all diagnostic relevant species, of which some are growing sparsely. A similar size $\left(50-100 \mathrm{~m}^{2}\right)$ is suggested by Müller-Dombois and Ellenberg (1974) for dry grassland, but $10-25 \mathrm{~m}^{2}$ for productive meadows and $5-10 \mathrm{~m}^{2}$ for fertilized pastures may suffice according to the same authors. The size of the optimal survey area can also be determined by compiling a chart showing the relationship between species number and the size of the investigated area. Within a frame of a certain size (e.g., $0.5 \times 0.5 \mathrm{~m}$ ), the number of species is recorded and then this frame is turned over as often, as there is no more increase of the cumulated number of species. The species number is then plotted against the area size to infer the minimum size required. The point of inflection of the curve, representing the size at which the increase in species number declines, can be considered a good compromise between the required effort and detection of most species (Whalley and Hardy, 2000), whilst the area size at which no further species increase is attained represents the minimum area necessary to retrieve all species.

As in field experiments the size of the survey area is limited by the plot size, only the central, homogenous part should be used to avoid boundary effects. Considering this requirement, and given a certain plot area, a circular form of the plots allows to reduce the boundary effects to a minimum, but it bears the disadvantage of being less easily combinable with other plots within a field design. Furthermore, the boundaries of a circular form are more difficult to delimit on the field and to manage (i.e., fertilization or harvest) than quadrats or rectangles. Quadrats have a smaller boundary proportion than any other rectangle, whilst a rectangular form presents an increasing boundary proportion with increasing length of the longer side. However, in case of assessments to be performed without entering the plots, in order to avoid trampling the vegetation, rectangles allow a better visual and/or physical access to the plot area (Traxler, 1997). Transects are an extension of the rectangular form and are appropriate whenever changes of the vegetation are to be detected or described along a predefined path encompassing environmental gradients (Whalley and Hardy, 2000). Some methods to assess cover and frequency (i.e., point quadrats, linear analysis) are performed along transects, which can be also positioned within plots.

Both the number of recordings and the size of the survey areas should be adapted to the site homogeneity and to the used investigation method. Heterogeneous grasslands, which often occur in large grazed plots, poses particular challenges to describe the vegetation. In such cases, as it is not possible to assess the total area, it is advisable to repeat the assessments on a sufficient number of small subareas (pseudo-replicates) adequately reflecting the reality on average. Random location is appropriated if the heterogeneity is not extreme and the method chosen allows for a large number of observations without excessive increase of the time effort. In this case, however, caution is required to avoid unconscious bias in the choice of the subareas (Whalley and Hardy, 2000). Fixed grid sampling (and, in

Table 2. Information about forage yield, forage quality and suitability for forage conservation deducible from the sward type

Tabelle 2. Aus dem Pflanzenbestandestyp ableitbare Informationen über Futterertrag, Futterqualität und Eignung zur Futterkonservierung

\begin{tabular}{|c|c|c|c|c|}
\hline Sward type & Rich in grasses & Balanced & Rich in forbs & Rich in legumes \\
\hline Yield potential & ++ & + & + & - \\
\hline Crude protein potential & - & + & + & ++ \\
\hline $\begin{array}{l}\text { Forage quality stability along phenological development at } \\
\text { the first cut }\end{array}$ & - & + & + & ++ \\
\hline Easiness of silage conservation & ++ & + & - & - \\
\hline Drying speed & ++ & + & $-a^{a}$ & + \\
\hline Risk of crumbling losses & - & - & + & + \\
\hline Risk of contamination with soil & - & - & + & $+/++$ \\
\hline
\end{tabular}

++ high, + medium, - low; a particularly in case of forbs with rough stems 



Figure 9. Different frames used for the point intercept method

Abbildung 9. Unterschiedliche Rahmenbauweisen für die Durchführung der Punkt-Quadrat-Methode 
general, planning in advance the position within the plots of the areas to be sampled) overcomes this problem. It also allows better detection of temporal changes by means of repeated measurements, if the assessments are performed over time at the same position. Stratified random sampling is appropriated in case of clear patterns: in this case, the number of subareas for each occurring sward type is determined proportionally to its total area within the plot and then the single sampling areas are assigned randomly within the respective type (Whalley and Hardy, 2000).

The number of replicates necessary to detect significant differences between treatments is subject to statistics theory and can be estimated given the aspired width of the confidence interval and precision (smallest relevant difference between expected and observed mean) (Traxler, 1997).

\section{Methods to describe grassland vegetation}

Different methods have been developed and used in the previous century all over the world to describe grassland vegetation (Hanson, 1934; Braun-Blanquet, 1951; Johnston, 1957; Schechtner, 1958). Numerous authors have given attention to reliability, replicability and comparability of different methods (Goodall, 1952; Tüxen, 1972; Greig-Smith, 1983; Everson et al., 1990; Lepš and Hadincová, 1992; Grant, 1993; Traxler, 1997). The most frequently used methods are described in the next paragraphs, with the description mainly focusing on the operative issues. This allows clustering the methods, for the sake of clarity, in just few categories.

\subsection{Visual estimation methods}

The main advantage of this method is the independency from technical devices and the low time expenditure. Voigtländer and Voss (1979) as well as Dethier et al. (1993) assert that, under favorable conditions, visual estimation methods are competitive with objective methods in terms of accuracy. However, accuracy of estimate depends on several factors (Traxler, 1997):

- size of the area to be assessed (the smaller the more precise)

- pattern of distribution (compact spots are easier to estimate than single individuals or scattered plants)

- growth habit (tussocks and rosettes are easier to estimate than, e.g., grasses)

- morphological differentiation of species (easiness in distinguishing species one from another)
- stratification of the plant community (grassland is assumed to be especially difficult to estimate)

- flowering aspect (flowering plants are often overestimated)

- possibility to enter the survey area (in experimental plots, estimation must be mostly performed from outside the plots to avoid disturbance; this makes the judging of the projective cover more difficult).

Furthermore, the subjective condition, training level, experience and routine of the observer play an important role (Peratoner et al., 2018). Observations at the end of a long working day are for instance less precise than those at the beginning of a day. Moreover, previous knowledge of the botanical composition of the surveyed plot or of the plant community under survey allows the observer a targeted search for species that are expected to be found. In the ideal case, the investigated areas should always be surveyed by the same person (Vittoz and Guisan, 2007). Even though some systematic, subjective error of estimate occurs, sufficient and reliable comparisons between different treatments can be obtained by means of this procedure. Visual estimations are mainly suitable for determining cover and yield proportion.

Following the method by Klapp/Stählin (Klapp, 1930; cited in Voigtländer and Voss, 1979), the yield proportion of particular species related to the entire above ground biomass $(=100 \%)$ is estimated and this can be done quickly by experienced observers. Usually, a list of all occurring species is compiled and then the yield proportion of species groups (grasses, including sedges and rushes, herbs and legumes) are estimated. The proportion of these groups is then allotted between the single species, typically starting with poorly represented species, which are easier to estimate. According to Traxler (1997), visual estimation of cover is the most used method in vegetation ecology for reasons of quick realization and sufficient accuracy. At AREC Raumberg-Gumpenstein, a modified version of the Braun-Blanquet method (1951) was established by Schechtner (1958). In contrast to five-part to nine-part ordinal scales, which are often used in plant sociology and botany, a percentage-scale is used to estimate the cover of single species (CS). This method needs a lot of experience, routine and is quite time consuming. In practice, initially, all occurring species at the observed site are recorded and allotted to the groups of tall grasses, medium grasses, bottom grasses, graminoids (sedges and rushes), legumes and forbs. Then, the cover of all single species is estimated as 
area- $\%$, whereas the following symbols are used to determine very low cover values:

$++=$ rare $(=0.66$ area $-\%),+=$ very rare $(=0.33$ area- $\%)$ and $r$ for species with one or two individuals occurring in the survey area

Following the determination of all single species, the total area proportion within the plant groups as well as the overall vegetation cover $(\mathrm{CV})$ is calculated (= sum of group cover resp. sum of species cover). In tall and dense grassland stands, the total cover can amount to 130-140 area$\%$, whereas in short and sparse grassland stands, this value can even fall under $100 \%$. Validation of the results can be done in different ways, for example, as a comparison with other observation areas to decide whether the total cover is too high or too low. In addition, the cover of single species or species groups can be compared.

In field experiments, treatments are usually replicated several times, mostly providing a different total cover of vegetation (CV). This must be considered, when the mean cover of a plant species is calculated. For this reason, the cover proportion of species can be standardized (CSZ) as follows:

$$
C S Z=\frac{C S}{C V} \times 100
$$

CSZ $=$ standardized cover proportion of a species

$\mathrm{CS}=$ cover proportion of a species $($ area- $\%)$

$\mathrm{CV}=$ total cover of vegetation $($ area- $\%)$

$$
\mathrm{CV}=\sum_{x=1}^{n} \mathrm{C} S_{x}
$$

The example in Table 3 shows a considerable difference of approximately 4 area- $\%$ between the uncorrected (CS) and the standardized (CSZ) mean value.

\subsection{Estimation frame (counting frame, frequency frame)}

The use of wooden or metal frames provides a precise definition of the area to be surveyed. However, one critical point is the decision whether plants that are partly outside the frame have to be included in the observation or not. Usually, rooting within the frame is the relevant criterion for this decision. Nevertheless, the decision remains partly subjective for plants growing at the frame's margins. More-
Table 3. Calculation example for the mean cover proportion of a species (CS) occurring in replicate plots with different total cover of vegetation $(\mathrm{CV})$

Tabelle 3. Berechnungsbeispiel zur Ermittlung des durchschnittlichen Deckungsgrades einer Art (CSmean) bei Vorliegen unterschiedlicher Gesamtdeckungsgrade (CV) in Wiederholungsflächen

\begin{tabular}{cccc}
\hline Replicate plot & CS (area-\%) & CV (area-\%) & CSZ (area-\%) \\
\hline 1 & 20 & 140 & 14.3 \\
2 & 25 & 110 & 22.7 \\
3 & 20 & 125 & 16.0 \\
4 & 25 & 115 & 21.7 \\
\hline Average & 22.5 & 121.3 & 18.7 \\
\hline
\end{tabular}

over, the size of the frame is relevant in this respect: the smaller the frame, the higher is the proportion of plants at the frame's margins and the higher is the risk of wrong decisions (Müller-Dombois and Ellenberg, 1974). In grassland science frames with a size of $0.5 \times 0.5 \mathrm{~m}$ or $1.0 \times 1.0 \mathrm{~m}$ are frequently used (Whalley and Hardy, 2000). Such frames can be used for the estimation of cover, plant density or frequency.

For frequency measurements, frames are typically subdivided into 100 quadrats and in each of them the occurrence of every single species is recorded. The number of quadrats, in which a single species occurs, is representing its frequency. Circular frames with a size of $0.1 \mathrm{~m}^{2}$ can be used for a random selection of observation spots by throwing the frames repeatedly followed by recording the species occurring within the frame.

\subsection{Point quadrats, point intercept}

This method is known as the point intercept method, point quadrats or point method (Levy and Madden, 1933; Goodall, 1952; Goodall, 1953). With this method, the occurrence of a species is not recorded within a certain area, but at a defined point. Usually, wire pins are vertically lowered downwards at the intersection points of a grid frame or through regularly spaced holes (guide channels) in a frame (Figure 9). The contact point between the pin and the vegetation identifies the species to be recorded. If leaf area index (LAI) is the targeted parameter, an angle of $32.5^{\circ}$ of the pins to the horizontal minimizes the error due to the underestimation of the foliage area of species with erect habit of foliage (Wilson, 1960).

In France and Italy, a modified point intercept method is frequently used for surveys on pastures. For this so-called 
linear analysis, according to Daget and Poissonet (1971), a metal bar or a bayonet is stuck into the soil along a measuring tape at regular distances (Ostermann, 1991). Again, the contact between the bar (or bayonet edge) and a plant defines the species that is recorded.

The point intercept method can be used for assessing the top cover if only the first contact is recorded, but also for frequency measurements, provided that all contacts per observation point are recorded. When all contacts per point, including the repeated contacts of the same species at the same point are recorded, specific proportion can be derived and seen as a relative expression of aboveground biomass (Goodall, 1952; Ostermann, 1991). This type of recordings can also be done with the help of telescopic tubes, in which the function of wires is replaced by crosshairs (Traxler, 1997). The point intercept method offers better objectivity and accuracy for investigations of vegetation dynamics than visual estimate (Stampfli, 1991; Vittoz and Guisan, 2007). However, there is some disadvantage due to the high time effort and in case of windy conditions and tall vegetation, which can impede the measurements or even make them impossible. There is also the need of a high number of replicates to catch rare species (Traxler, 1997). As an acceptable compromise, species that are not intercepted but occur in the surveyed area can be added to the species list with a frequency of less than $1 \%$ (Peratoner, 2003; Pittarello et al., 2018).

\subsection{Manual separation of yield}

Theoretically, an exact determination both on species level and species group level, can also be carried out by extremely time-consuming manual separation of the harvested yield. Therefore, manual separation in grassland is mostly done with defined subsamples for the species groups of grasses, herbs and legumes to search for their functional traits and their impact on specific parameters like crude protein or carbohydrate fractions (Pötsch and Resch, 2007; Weichselbaum, 2015; Gabauer, 2018).

\subsection{Methods relying on digital acquisition of data}

These methods, including both proximal and remote sensing, imply the availability of instruments to capture, process and record information related to the vegetation under survey. Their main advantages are the ability to collect large amount of data in short time, thus reducing labor and time effort and, in case of remote sensing, the pos- sibility to collect data also from remote or hardly accessible locations, potentially covering every location in time and space (Wachendorf et al., 2018). Great advance has been achieved in the last two decades in estimating biomass and forage quality mainly, but they have proved to be suitable also in providing valuable information about other parameters related to the botanical composition of the sward, as long as i) there is only one target species, or ii) the botanical composition is simple, or iii) an information at a community level fulfils the aim of the survey. For instance, photography and digital image analysis (DIA) have been shown to provide reliable information about cover and yield proportion of legumes in binary clovergrass mixtures (Himstedt et al., 2010) and to allow the automatic detection of a broad-leaved weed (Rumex obtusifolius) in grassland (Gebhardt et al., 2006; Gebhardt and Kühbauch, 2007). Strong emphasis is currently placed on spectrometry, a non-invasive method that allows analyzing biological systems in terms of components, structures and molecular functions. Vegetation and its growth dynamics can be described at a community level by means of various indices derived from field-spectrometric measurements and partly related also to vegetation traits (i.e., vegetation mapping, species richness) at a community level (Govender et al., 2007; Psomas et al., 2011; Hollberg and Schellberg, 2017). Spectrometric techniques can also be used for detecting weeds (Glenn et al., 2005) or, as expected in future, for estimating the optimal time of harvesting in combination with satellite data (Schaumberger and Schellberg, 2015). However, compared to the manual and visual methods, spectrometry requires both costly equipment and advanced knowledge in data processing as well.

\subsection{Information derivable from botanical assessments}

It must not be forgotten that data describing the botanical composition of the vegetation can be used to derive further parameters useful to summarize and synthesize the information gained by the assessments. They allow to quantify diversity and compute community-weighted means to characterize the vegetation from an ecological and agronomical point of view.

\subsubsection{Diversity}

To describe diversity in grassland vegetation, the number of species per unit area (species richness) is the most used parameter, if only qualitative information (presence/absence of the species) is considered. Three types of diver- 
sity in terms of species richness are distinguished (Gauch, 1982): i) the number of species recorded per unit area is called alpha diversity, ii) beta diversity is the betweencommunity component of diversity (Chao et al., 2012), while iii) gamma diversity is the total number of species encountered in the entire study. The definition of beta diversity has been largely debated (Moreno and Rodriguez, 2010) and, depending on the different authors, can be represented by changes in species composition among different communities in a landscape, by the amount of species turnover along management or environmental gradients or by the relative distribution of species richness across scales. Beta diversity can be quantified using measurements of similarity or distance (i.e., Euclidean distance) (Gauch, 1982; Whalley and Hardy, 2000; Vellend, 2001), or it can be computed in several ways from alpha and gamma diversities (Tuomisto, 2010; Chao et al., 2012).

If quantitative data (i.e., cover or yield proportion of the species) is considered to describe diversity, other indices can be used to provide a measure of diversity (see e.g. Magurran, 1988 for an overview of the most common indices and their calculation). The Shannon index is the most frequently used index. Its value increases with rising number of species and increasing similarity of the proportion (evenness) of the single species up to a maximum value (in case all species have the same proportion) equal to the natural logarithm of the number of species. A quantification of evenness (Shannon evenness measure), ranging between a value close to zero and one and independent from the species number, can be as well derived from the Shannon index.

\subsubsection{Ecological and agronomical indicators}

A broad range of species-specific indicators or traits can be used to compute community-weighted means. They are obtained as the mean of the indicator or trait of interest weighted by one of the parameters quantitatively describing the botanical composition.

In vegetation ecology, indicator values can be usually combined with both cover or yield proportion data (Spatz et al., 1979; Briemle, 1997; Bohner, 2015). With this regard, several options are available, ranging from Ellenberg's (Ellenberg, 1979) and Landolt's (Landolt et al., 2010) indicator values for several ecological site factors to the competition strategies according to Grime (Grime, 1977; Grime, 2001; Frank and Klotz, 1990; Landolt et al., 2010), reproductive functional strategy types (Klotz et al., 2002) or plant functional traits (Lavorel et al., 2008; Schellberg and Pontes, 2012).
From an agronomical perspective, the calculation of community-weighted means can be best done using the specific contribution or yield proportion of species (Peeters, 2015). Most common are the potential forage value according to Klapp ("Bestandeswertzahl nach Klapp") (Klapp, 1971; Spatz et al., 1979), the pastoral value according to Daget and Poissonet (1971) and other indicator values comprising mowing tolerance, grazing tolerance and trampling tolerance (Briemle et al. 2002; Landolt et al., 2010).

\section{Conclusions}

The selection of appropriate methods to characterize and describe the botanical composition in grassland research should follow various criteria (Table 4). The target of the investigation primarily determines the selection of parameters to be recorded. If, for example, the focus of investigation is set on forage quality, the determination of yield proportion as a direct reference to biomass is recommended. However, if the main interest is put on species distribution and its changes over time, this can be achieved best by recording frequency. Finally, the selection of appropriate methods for specific parameters also depends on the expected and achievable accuracy, as well as on the acceptable effort and on the available resources.

\section{Acknowledgements}

This paper is a revised, enhanced and extended version of the conference paper in German language "Peratoner, G. and E.M. Pötsch (2015): Erhebungsmethoden des Pflanzenbestandes im Grünland. In: Höhere Bundeslehr- und Forschungsanstalt für Landwirtschaft Raumberg-Gumpenstein (Ed.): Bericht über das 20. Alpenländische Expertenforum zum Thema Bedeutung und Funktionen des Pflanzenbestandes im Grünland. HBLFA RaumbergGumpenstein, Irdning, pp. 15-22". The drawings of the plant species used for the graphic examples provided in Figure 1, 2, 4, 5, 6 and 7 have been developed based on drawings in Simonetti and Watschinger (1986).

We thank A. Schaumberger for his expert opinion about the chapter on methods relying on digital acquisition of data and two anonymous reviewers for their constructive comments, which helped to improve the paper. 
Table 4. Suitability and specific properties of selected survey methods for grassland vegetation

Tabelle 4. Eignung und spezifische Eigenschaften ausgewählter Erhebungsmethoden für Pflanzenbestände im Grünland

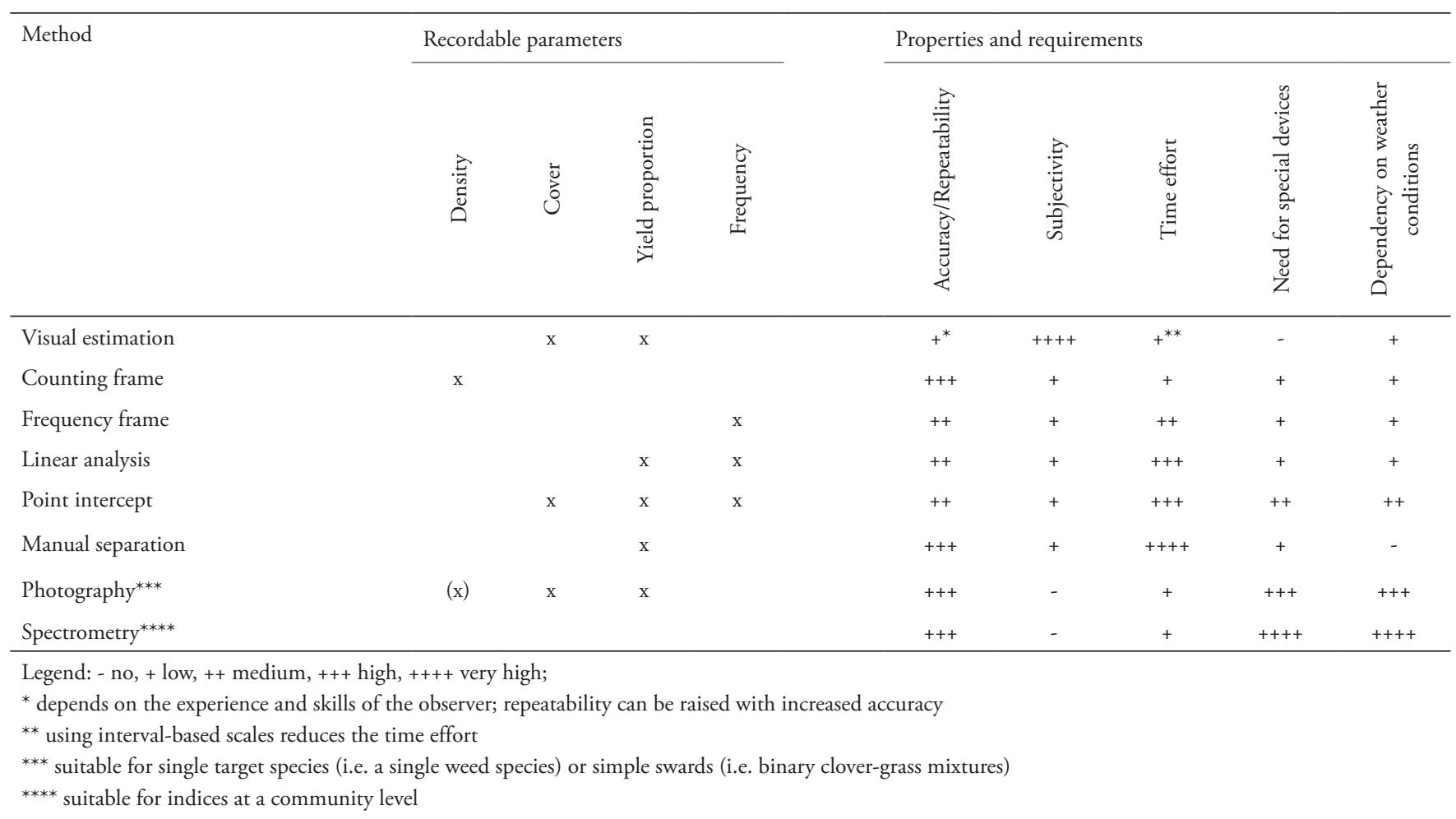

\section{References}

Bohner, A. (2015): Bedeutung und Aktualität von Zeigerpflanzen im Grünland. In: Höhere Bundeslehr- und Forschungsanstalt für Landwirtschaft Raumberg-Gumpenstein (Ed.): Bericht über das 20. Alpenländische Expertenforum zum Thema Bedeutung und Funktionen des Pflanzenbestandes im Grünland. HBLFA Raumberg-Gumpenstein, Irdning, pp. 39-44.

Bohner, A. and M. Sobotik (2000): Das Wirtschaftsgrünland im Mittleren Ennstal aus vegetationsökologischer Sicht. In: Bundesanstalt für Alpenländische Landwirtschaft Gumpenstein (Ed.): MAB-Forschungsbericht. Landschaft und Landwirtschaft im Wandel. Das Grünland im Berggebiet Österreichs. 22-23 September 2000, Wien. Bundesanstalt für alpenländische Landwirtschaft Gumpenstein, pp. 15-50.

Bonham, C.D. (2013): Measurements for terrestrial vegetation. $2^{\text {nd }}$ ed., Wiley, Hoboken, 246 pp.

Bornkamm, R. and U. Hennig (1982): Experimentell-ökologische Untersuchungen zur Sukzession von ruderalen Pflanzengesellschaften auf unterschiedlichem Boden. I. Zusammensetzung der Vegetation. Flora 172, 267-316.
Briemle, G. (1997): Zur Anwendbarkeit ökologischer Wertzahlen im Grünland. Angewandte Botanik 71, 219-228.

Briemle, G., Nitsche, S. and L. Nitsche (2002): Nutzungswertzahlen für Gefäßpflanzen des Grünlandes. Schriftenreihe für Vegetationskunde 38, 203-225.

Braun-Blanquet, J. (1951): Pflanzensoziologische Grundzüge der Vegetationskunde. $2^{\text {nd }}$ ed., Springer-Verlag, Wien, $631 \mathrm{pp}$.

Burrough, P.A. (1986): Principles of Geographic Information Systems for Land Resource Assessments. Oxford University Press, Oxford, 193 pp.

Chao, A., Chiu, C.-H. and T.C. Hsieh (2012): Proposing a resolution to debates on diversity partitioning. Ecology 93, 2037-2051.

Copeland, O.L. (1965): Land use and ecological factors in relation to sediment yields. Proceedings of the Federal Inter-Agency Sedimentation Conference 2, 72-84.

Daccord, R., Wyss, U., Jeangros, B. and M. Meisser (2007): Bewertung von Wiesenfutter. Nährstoffgehalt für die Milch- und Fleischproduktion. AGFF-Merkblatt 3, Arbeitsgemeinschaft zur Förderung des Futterbaus (AGFF), Zürich, 6 pp. 
Daget, P. and J. Poissonet (1971): Une méthode d'analyse phytologique des prairies. Critères d'application. Annales Agronomique 22, 5-41.

Dethier, M.N., Graham, E.S., Cohen, S. and L.M. Tear (1993): Visual versus random-point percent cover estimations: 'objective 'is not always better. Marine Ecology Progress Series 96, 93-100.

Dierschke, H. (1994): Pflanzensoziologie. Verlag Eugen Ulmer, Stuttgart, $683 \mathrm{pp}$.

Dietl, W. (1995): Wandel der Wiesenvegetation im Schweizer Mittelland. Zeitschrift für Ökologie und $\mathrm{Na}$ turschutz 4, 239-249.

Ellenberg, H. (1979): Zeigerwerte der Gefäßpflanzen Mitteleuropas. 2. verbesserte und erweiterte Auflage. Studia Geobotanica 9, 122 pp.

Everson, T.M., Clarke, G.P.Y. and C.S. Everson (1990): Precision in monitoring plant species composition in montane grasslands. Vegetatio 88, 135-141.

Frame, J. and A.S. Laidlaw (2014): Improved grassland management. Crowood Press, New York, 352 pp.

Frank, D. and S. Klotz (1990): Biologisch-ökologische Daten zur Flora in der DDR. Wissenschaftliche Beiträge 32/P41. Martin-Luther-Universität Halle-Wittenberg, Halle (Saale), 167 pp.

Gabauer, J. (2018): Auswirkung verschiedener Düngungsvarianten im Dauergrünland auf die in vitro-Verdaulichkeit und den Energiegehalt des Futters. Masterarbeit, Universität für Bodenkultur Wien, 108 pp.

Gauch, H.G. (1982): Multivariate analysis in community ecology. Cambridge University Press, Cambridge, 298 pp.

Gebhardt, S. and W. Kühbauch (2007): A new algorithm for automatic Rumex obtusifolius detection in digital images using colour and texture features and the influence of image resolution. Precision Agriculture 8, 1-13.

Gebhardt, S., Schellberg, J., Lock, R. and W. Kühbauch (2006): Identification of broad-leaved dock (Rumex obtusifolius L.) on grassland by means of digital image processing. Precision Agriculture 7, 165-178.

Glenn, N.F., Mundt, J.T., Weber, K.T., Prather, T.S., Lass, L.W. and J. Pettingill (2005): Hyperspectral data processing for repeat detection of small infestations of leafy spurge. Remote Sensing of Environment 95, 399-412.

Goodall, D.W. (1952): Some considerations in the use of point quadrats for the analysis of vegetation. Australian Journal of Scientific Research 5, 1-41.

Goodall, D.W. (1953): Point quadrat methods for the analysis of vegetation. The treatment of data for tussock grasses. Australian Journal of Botany 1, 457-461.
Govender, M., Chetty, K. and H. Bulcock (2007): A review of hyperspectral remote sensing and its application in vegetation and water resource studies. Water SA 33, $145-152$.

Grant, S.A. (1993): Resource description: vegetation and sward components. In: Davies, A., Baker, R.D., Grant, S.A. and A.S. Laidlaw (Eds): Sward measurements handbook. $2^{\text {nd }}$ ed., The British Grassland Society, Reading, pp. 69-97.

Greig-Smith, P. (1983): Quantitative plant ecology. $3^{\text {rd }}$. ed., University of California Press, Berkeley, Los Angeles, $360 \mathrm{pp}$.

Grime, J.P. (1977): Evidence for the existence of three primary strategies in plants and its relevance to ecological and evolutionary theory. The American Naturalist 111, 1169-1194.

Grime, J.P. (2001): Plant strategies, vegetation processes and ecosystem properties, second edition, Wiley, Chicester, 456 pp.

Gusmeroli, F. (2012): Prati, pascoli e paesaggio alpino. SoZooAlp, San Michele all'Adige, 264 pp.

Hanson, H.C. (1934): A comparison of methods of botanical analysis of the native prairie in western North Dakota. Journal of Agricultural Research 49, 815-842.

Himstedt, M., Fricke, T. and M. Wachendorf (2010): The relationship between coverage and dry matter contribution of forage legumes in binary legume-grass mixtures. Crop Science 50, 2186-2193.

Hollberg, J. and J. Schellberg (2017): Distinguishing intensity levels of grassland fertilization using vegetation indices. Remote Sensing 9, 81.

Höhn, E. (1988): Abtrocknung und Ernteverlust von kräuterreichen Wiesen. Schweizerische Landwirtschaftliche Forschung 27, 181-189.

Kirmer, A. (2004): Methodische Grundlagen und Ergebnisse initiierter Vegetationsentwicklung auf xerothermen Extremstandorten des ehemaligen Braunkohletagebaus in Sachsen-Anhalt. Dissertationes Botanicae, 385. Cramer, Berlin, Stuttgart, 167 pp.

Klapp, E. (1930): Zum Ausbau der Graslandbestandsaufnahme zu wissenschaftlichen Zwecken. Pflanzenbau 6, 197-210.

Klapp, E. (1971): Wiesen und Weiden. Verlag Parey, Berlin, $620 \mathrm{pp}$.

Klotz, S., Kühn, I. and W. Durka (2002): BIOLFLOR Eine Datenbank mit biologisch-ökologischen Merkmalen zur Flora von Deutschland. Schriftenreihe für Vegetationskunde 38. Bundesamt für Naturschutz, Bonn, 334 pp. 
Johnston, A. (1957): A comparison of the line interception, vertical point quadrat, and loop methods as used in measuring basal area of grassland vegetation. Canadian Journal of Plant Science 37, 34-42.

Jones, R.M. and J.N.G. Hargreaves (1979): Improvements to the dry-weight-rank method for measuring botanical composition. Grass and Forage Science 34, 181-189.

Landolt, E., Erhardt, A., Hegg, O., Klötzli, F., Lämmler, W., Nobis, M., Rudmann-Maurer, K., Schweingruber, F.H., Theurillat, J.-P., Urmi, E., Vust, M. and T. Wohlgemuth (2010): Flora indicativa: ökologische Zeigerwerte und biologische Kennzeichen zur Flora der Schweiz und der Alpen. Haupt, Bern, 378 pp.

Lavorel, S., Grigulis, K., McIntyre, S., Williams, N.S.G., Garden, D., Dorrough, J., Berman, S., Quétier, F., Thébault, A. and A. Bonis (2008): Assessing functional diversity in the field - methodology matters! Functional Ecology 22, 134-147.

Lepš, J. and V. Hadincová (1992): How reliable are our vegetation analyses? Journal of Vegetation Science 3, 119-124.

Levy, F.B. and E.A. Madden (1933): The point method of pasture analysis. New Zealand Journal of Experimental Agriculture 46, 267-279.

Linse, S.J., Mergen, D.E., Smith, J.L. and M.J. Trlica (2001): Upland erosion under a simulated most damaging storm. Journal of Range Management 54, 356-361.

Londo, G. (1976): The decimal scale for releves of permanent quadrats. Vegetatio 33, 61-64.

Magurran, A.E. (1988): Ecological diversity and its measurement. Princeton University Press, Princeton, 256 pp.

Mannetje, L.T. and K.P. Haydock (1963): The dry-weightrank method for measuring botanical composition. Journal of the British Grassland Society 18, 268-275.

Moreno, C.E. and P. Rodríguez (2010): A consistent terminology for quantifying species diversity? Oecologia 163, 279-282.

Müller-Dombois, D. and H. Ellenberg (1974): Aims and methods of vegetation ecology. John Wiley and Sons, New York, Sydney, London, Toronto, 547 pp.

Nußbaum, H., Weißbach, F., Elsäßer, M., Schenkel, H., Staudacher, W., von Borstel, U., Groß, F., Seibold, R. and J.B. Rieder (1999): Grundfutterbewertung. Teil A: DLG-Schlüssel zur Bewertung von Grünfutter, Silage und Heu mit Hilfe der Sinnenbewertung. DLG-Information 2/1999. Deutsche Landwirtschafts-Gesellschaft, Frankfurt.
Onofri, A., Piepho, H.-P. and M. Kozak (2019): Analysing censored data in agricultural research: A review with examples and software tips. Annals of Applied Biology 174, 3-13.

Ostermann, O. (1991): Der Einfluß der Schafweide auf die Vegetationsdynamik der subalpinen Hakenkiefernbestände (Pinus uncinata Mill. ex Mirbel). Methoden und Ergebnisse im Vercors, Frankreich. Dissertation, Georg-August-Universität Göttingen, Göttingen.

Peeters, A. (2015): Synthesis of systems of European grassland typologies at plot, farm and region levels. Grassland Science in Europe 20, 116-118.

Peratoner, G. (2003): Organic seed propagation of alpine species and their use in ecological restoration of ski runs in mountain regions. Kassel University Press, Kassel, $240 \mathrm{pp}$.

Peratoner, G. and E.M. Pötsch (2015): Erhebungsmethoden des Pflanzenbestandes im Grünland. In: Höhere Bundeslehr- und Forschungsanstalt für Landwirtschaft Raumberg-Gumpenstein (Ed.): Bericht über das 20. Alpenländische Expertenforum zum Thema Bedeutung und Funktionen des Pflanzenbestandes im Grünland. HBLFA Raumberg-Gumpenstein, Irdning, pp. 15-22.

Peratoner, G., Kasal, A., Florian, C. and M. Pramsohler (2018): Accuracy of visual assessment of the plant stand type for the estimation of forage quality. Grassland Science in Europe 23, 950-952.

Peratoner, G., Romano, G., Piepho, H.-P., Bodner, A., Schaumberger, A., Resch, R. and E.M. Pötsch (2016a): Suitability of different methods to describe the botanical composition for predicting forage quality of permanent meadows at the first cut. Grassland Science in Europe 21, 311-313.

Peratoner, G., Romano, G., Schaumberger, A., Piepho, H.-P., Resch, R. and A. Bodner (2016b): webGRAS: a web application to estimate the potential forage quality of mountain permanent meadows. Grassland Science in Europe 21, 203-205.

Pittarello, M., Lonati, M., Gorlier, A., Perotti, E., Probo, M. and G. Lombardi (2018): Plant diversity and pastoral value in alpine pastures are maximized at different nutrient indicator values. Ecological Indicators 85, 518-524.

Pfadenhauer J., Poschlod, P. and R. Buchwald (1986): Überlegungen zu einem Konzept geobotanischer Dauerbeobachtungsflächen für Bayern. Teil 1. Methodik der Anlage und Aufnahme. Berichte der ANL 10, Akade- 
mie für Naturschutz und Landschaftspflege, Laufen/ Salzach, pp. 41-60.

Pötsch, E.M. and R. Resch (2007): In-vitro digestibility and energy concentration of different legumes - results from the COST 852 experiment in Austria. In: Helgadottir, A. and E.M. Poetsch (Eds.): Quality legumebased forage systems for contrasting environments. Book of abstracts: Final Meeting of COST 852, HBLFA Raumberg-Gumpenstein, pp. 145-148.

Psomas, A., Kneubühler, M., Huber, S., Itten, K. and N.E. Zimmermann (2011): Hyperspectral remote sensing for estimating aboveground biomass and for exploring species richness patterns of grassland habitats. International Journal of Remote Sensing 32, 9007-9031.

Resch, R., Peratoner, G., Frank, P., Stögmüller, G. and F. Tiefenthaller (2014): Futterverschmutzung mit Erde - Ursachen und Lösungsansätze. Der fortschrittliche Landwirt 92, 20-25.

Schaumberger, A. and J. Schellberg (2015): Spektrometrie - moderne, nicht invasive Erfassungstechnik von Pflanzenbeständen. In: Höhere Bundeslehr- und Forschungsanstalt für Landwirtschaft Raumberg-Gumpenstein (Ed.): Bericht über das 20. Alpenländische Expertenforum zum Thema Bedeutung und Funktionen des Pflanzenbestandes im Grünland. HBLFA RaumbergGumpenstein, Irdning, pp. 23-32.

Schechtner, G. (1958): Grünlandsoziologische Bestandsaufnahme mittels "Flächenprozentschätzung". Zeitschrift für Acker- und Pflanzenbau 105, 33-43.

Schellberg, J. und L.d.S. Pontes (2012): Plant functional traits and nutrient gradients on grassland. Grass and Forage Science 67, 305-319.

Simonetti, G. and M. Watschinger (1986): Guida al riconoscimento delle erbe di campi e prati. Arnoldo Mondadori Editore, Milan, 304 pp.

Spatz, G., Pletl, L. and A. Mangstl (1979): Programm OEKSYN zur ökologischen und synsystematischen Auswertung von Pflanzenbestands-aufnahmen. In: Ellenberg, H. (Ed.): Zeigerwerte der Gefäßpflanzen Mitteleuropas. Scripta Geobotanica IX, $2^{\text {nd }}$ ed., Verlag Erich Goltze, Göttingen, 29-36.

Stampfli, A. (1991): Accurate determination of vegetational change in meadows by successive point quadrat analysis. Vegetatio 96, 185-194.

Tothill, J.C., Hargreaves, J.N.G., Jones, R.M. and C.K. McDonald (1992): BOTANAL - A comprehensive sampling and computing procedure for estimating pasture yield and composition. 1. Field sampling. Tropical Agronomy
Technical Memorandum, 8. CSIRO Division of Tropical Crops and Pastures St. Lucia, Brisbane, 24 pp.

Troxler, J. and P. Thomet (1988): Untersuchungen zur Ertragsleistung von kräuterreichen Wiesen. Schweizerische Landwirtschaftliche Forschung 27, 167-180.

Traxler, A. (1997): Handbuch des vegetationsökologischen Monitorings. Methoden, Praxis, angewandte Projekte. Teil A: Methoden. Monographien, 89A Bundesministerium für Umwelt, Jugend und Familie, Wien, 397 pp. Tuomisto, H. (2010): A diversity of beta diversities: straightening up a concept gone awry. Part 1. Defining beta diversity as a function of alpha and gamma diversity. Ecography 33, 2-22.

Tüxen, R. (1972): Kritische Bemerkungen zur Interpretation pflanzensoziologischer Tabellen. In: van der Maarel, E. and R. Tüxen (eds.): Grundfragen und Methoden der Pflanzensoziologie. Bericht über das Internationale Symposion der Internationalen Vereinigung für Vegetationskunde 1970 in Rinteln, Springer, Dordrecht, $168-182$.

Van Der Maarel, E. (1979): Transformation of coverabundance values in phytosociology and its effect on community similarity. Vegetatio 39, 97-114.

Vellend, M. (2001): Do commonly used indices of $\beta$-diversity measure species turnover? Journal of Vegetation Science 12, 545-552.

Vittoz, P. and A. Guisan (2007): How reliable is the monitoring of permanent vegetation plots? A test with multiple observers. Journal of Vegetation Science 18, 413422.

Voigtländer, G. and N. Voss (1979): Methoden der Grünlanduntersuchung und -bewertung. Grünland - Feldfutter - Rasen. Verlag Eugen Ulmer, Stuttgart, 207 pp.

Wachendorf, M., Fricke, T. and T. Möckel (2018): Remote sensing as a tool to assess botanical composition, structure, quantity and quality of temperate grasslands. Grass and Forage Science 73, 1-14.

Weichselbaum, F. (2015): Auswirkung unterschiedlicher Düngungsniveaus im Dauergrünland auf die Proteinfraktionierung im Grundfutter. Masterarbeit, Universität für Bodenkultur Wien, 86 pp.

Weinzierl, T. (1902): Alpine Futterbauversuche, zugleich II. Bericht über die im alpinen Versuchsgarten auf der Sandlingalpe durchgeführten wissenschaftlich-praktischen Untersuchungen in den Jahren 1890-1900. Verlag W. Frick, k.k. Hofbuchhandlung, Wien, 276 pp.

Weißbach, F., Berg, K., Weise, G. and O. Knabe (1977): Methoden und Tabellen zur Schätzung der Vergärbar- 
keit. 3. Auflage, Akademie der Landwirtschaftswissenschaften der DDR, Leipzig, 53 pp.

Whalley R.D.B. and M.B. Hardy (2000): Measuring botanical composition of grasslands. In: Field laboratory methods for grassland and animal production research. In: Mannetje, L.T. and R.M. Jones (Eds.): Field and laboratory methods in grassland and animal production research, CAB International, Wallingford, pp. 67-102.

Wilmanns, O. (1989): Ökologische Pflanzensoziologie. $4^{\text {th }}$ ed., UTB 269, Quelle \& Meyer, Heidelberg, 382 pp.

Wilson, J.W. (1959): Inclined point quadrats. New Phytologist 59, 1-7.
Zacharias, D. (1996): Dauerbeobachtung; Konzepte und Beispiele aus der Praxis Niedersachsens (Vegetation Monitoring: Concepts and Examples of the Practical Work of Nature Conservation in Lower Saxony, a State of the Federal Republic of Germany). In: Umweltbundesamt (Ed.): Monitoring for Nature Conservation. 21-22 June 1996, Vienna, pp. 47-55. 